\title{
Humiliating Whistle-Blowers: Li Wenliang, the Response to Covid-19, and the Call for a Decent Society
}

\author{
Jing-Bao Nie • Carl Elliott
}

Received: 1 May 2020 / Accepted: 8 July 2020

(C) Journal of Bioethical Inquiry Pty Ltd. 2020

\begin{abstract}
The ethical experience and lessons of China's and the world's response to COVID-19 will be debated for many years to come. But one feature of the Chinese authoritarian response that should not be overlooked is its practice of silencing and humiliating the whistle-blowers who told the truth about the epidemic. In this article, we document the humiliation of Dr Li Wenliang (19862020), the most prominent whistle-blower in the Chinese COVID-19 epidemic. Engaging with the thought of Israeli philosopher Avishai Margalit, who argues that humiliation constitutes an injury to a person's self-respect, we discuss his contention that a decent society is one that abolishes conditions which constitute a justification for its dependents to consider themselves humiliated. We explore the ways that institutions humiliate whistle-blowers in Western countries as well as in China.
\end{abstract}

Keywords Whistle-blowing - China - Decent society · COVID-19 Public health ethics

J.-B. Nie

Bioethics Centre, University of Otago, PO Box 56, Dunedin 9054, New Zealand

C. Elliott $(\bowtie)$

Center for Bioethics, University of Minnesota, 410 Church St SE, Minneapolis, MN 55455-0346, USA

e-mail: ellio023@gmail.com
Debasement is the password of the base,

Nobility the epitaph of the noble.

See how the gilded sky is covered

With the drifting twisted shadows of the dead.

— "The Answer" by Bei Dao, 1976

In late December 2019, Dr. Li Wenliang, an ophthalmologist at Wuhan Central Hospital, became aware of a possible disease outbreak after seeing seven patients with SARS-like symptoms. Li warned colleagues and former classmates about the outbreak in a closed group on WeChat, the Chinese social media platform, suggesting that they take protective measures. Days after his warning, Li was censured by hospital leaders and summoned to the Public Security Bureau in Wuhan, where he was forced to sign a statement in which he was accused of spreading false rumours and disturbing the public order. Just over three weeks later, Wuhan, a city of over eleven million people, was placed under an unprecedented and draconian quarantine which would last seventy-six days. On February 7, 2020, Li died after becoming infected with SARS-CoV-2. He was thirty-three years old (Qin et al. 2020; BBC News 2020; Green 2020).

Li's death triggered an unprecedented public outpouring of grief and outrage within and outside China. The World Health Organization praised his work via social media. The United States Senate passed a resolution to commemorate his life. The hashtag \#WeWantFreedomOfSpeech received nearly two million views on Weibo before it was deleted. In response to the outcry, Chinese authorities conducted an official 
investigation into Li's treatment and reversed themselves. The personnel at the Public Security Bureau were blamed for their "irregular" and "improper" actions, while the Chinese government awarded Li with the title of "martyr," the highest honour the government can bestow on a citizen who dies while working to serve the state (Bostock 2020).

This dramatic reversal notwithstanding, it is worth noting just how far Chinese authorities went to humiliate $\mathrm{Li}$ when he first sounded the alarm about SARSCoV-2. By humiliation, we have in mind the sense of the term as explained by Israeli philosopher Avishai Margalit in The Decent Society - namely, as injury to a person's self-respect. Unlike most traditional political philosophers, who are preoccupied with the question of how to build a just society, Margalit is concerned with constructing a society that is not only just but also decent. According to Margalit, preventing humiliation to a society's weaker and more vulnerable members should be given priority even over respect for persons, just as treating diseases should have priority over promoting health. That doesn't mean that preventing humiliation is more important than preventing cruelty, of course. As Margalit writes, "Torturing the body causes more acute pain than torturing the soul" (Margalit 1996, 264). But preventing humiliation - inflicted by the state as well as by fellow citizens-remains an essential component of a decent society. Margalit writes, "A decent society is one that fights conditions which constitute a justification for its dependents to consider themselves humiliated" (Margalit 1996, 10).

How did Chinese authorities humiliate Li? First, the police assaulted Li's personal dignity and professional honour by forcing him to sign a false statement (Davidson 2020). According to his parents, Li was a person of great integrity who never really knew how to lie. To coerce Li to sign the document was to coerce an honest man to betray his principles. Li was forced to sign a letter of reprimand (xunjie shu)(Clarke 2020). It read as follows (our translation).

We now warn and admonish you about the violation of the law that you committed when you published untrue information on the internet. Your behaviour is out of compliance with what the law allows and violates the rules of the "Public Security Management Regulations of P.R. China.” It is illegal conduct. The Public Security Department hopes that you actively cooperate, follow the advice of the people's police, and stop your illegal behaviour. Can you do it?

Answer: [Yes, I] can.

We hope that you will calm down and think carefully. We also solemnly tell you: if you are stubborn so as not to express remorse instead of continuing to carry out illegal behaviour, you will be punished by the law. Do you understand this clearly?

Answer: [Yes, I] understand] clearly.

Li's answers and his signature were handwritten with his fingerprint in red. The document has the signatures of two "disciplining persons" as well as the official red seal of the branch of the Wuhan Bureau of Public Security.

Later, Li was humiliated publicly. On January 1, 2020, China Central Television (CCTC), a major official media outlet, broadcast nationwide that the Wuhan Bureau of Public Security had investigated and punished eight people, including Li, who spread untrue information about the virus on the internet (Ma and Mai 2020). The news item reported that the "eight rumour spreaders" had disturbed the social order and caused damaging social consequences. It instructed people not to believe or spread rumours. In China, this official move is sometimes called "killing chickens to show monkeys" (shaji geihoukan) — that is, sending a warning to others not to pursue similar actions.

Finally, Li was humiliated even in death. Officials initially declared Li dead at 9:30 p.m. on February 6. But when Chinese state media reported the death on social media, the result was a tide of anger so dramatic that government officials intervened. Wuhan Central Hospital released a statement reporting that $\mathrm{Li}$ was infected and in critical condition, and Li was reportedly placed on ECMO (extracorporeal membrane oxygenation) in order to keep him alive. Then Li was declared dead a second time at 2:58 a.m. on February 7, showing that even the date and time of a person's death can be manipulated in the service of state propaganda (Zhou 2020).

Ironically, it was not Li's intention to become a martyr or even a whistle-blower. In fact, he asked his colleagues and friends who received his warning messages not to share the information outside the WeChat group. It was only after he was forced to sign the 
document of admonition by the police that he shared information with the press. In an interview before his death, Li used "weiqu" to describe his feelings on being disciplined by the police (The New York Times 2020). This Chinese phrase is a soft expression on being wronged, similar to a child being falsely accused by her or his parents for misconduct never committed. "I felt I was being wronged, but I had to accept it," he told The New York Times. "Obviously I had been acting out of good will. I felt very sad seeing so many people losing their loved ones" (The New York Times 2020).

The purpose of whistle-blower protection laws in Western countries is to shield whistle-blowers from formal retaliation such as being fired or demoted. While these kinds of protections are clearly important, they don't do much to protect whistle-blowers from being ostracized, socially isolated, or humiliated in the workplace. And the fear of being humiliated can be an even stronger deterrent to potential whistle-blowers than the fear of being fired.

Most organizations understand this. As extreme as the actions taken against $\mathrm{Li}$ were, they merely represent the far end of a spectrum of actions routinely taken against whistle-blowers by organizations all over the world. "The usual practice is to demoralize and humiliate the whistleblower, putting him under so much psychological stress that it becomes difficult to do a good job," writes political scientist C. Fred Alford, who interviewed dozens of whistle-blowers for his book Whistleblowers: Broken Lives and Organizational Power. If whistle-blowers are placed under enough stress they will often make a mistake that justifies formal discipline. "A surprising number of whistleblowers have been given closets for offices," Alford writes. "One was ordered to go into his closet at nine and not come out until five" (Alford 2001, 32).

Jean Lennane, the former president of Whistleblowers Australia, reported that Australian whistle-blowers are routinely harassed through a variety of petty humiliations, such as "minute scrutiny of timesheets, impossible orders, referral for psychiatric assessment, repeated threats of disciplinary action." These humiliations do not come only from organizational leaders, but from friends and colleagues. Lennane writes, "One of the most distressing experiences for most whistleblowers is the lack of support, and sometimes active victimisation, from workmates. Particularly distressing are acts of betrayal by people who previously were close to them" (Lennane 2012, 252).

If one important purpose of humiliation is deterring potential whistle-blowers before they act ("killing chickens to show monkeys"), an equally important reason is to discredit actual whistle-blowers after they have acted. So when the whistle-blower questions the behaviour of the organization, the organization responds by questioning the psychological stability and moral character of the whistle-blower. Alford calls this the "nuts and sluts" strategy. He writes, "The key organizational strategy is to transform an act of whistleblowing from an issue of policy and principle into an act of private disobedience and psychological disturbance" (Alford 2001, 32).

That strategy has been liberally deployed during the SARS-CoV-2 pandemic. When U.S. Navy Captain Brett Crozier emailed a desperate plea for a response to the outbreak on the USS Theodore Roosevelt, the aircraft carrier he commanded, he was removed from his post and derided by acting Secretary of the Navy Thomas Modly as "naive" and "stupid" (Ismay and Ziezulewicz 2020.) When Adam Witt, a nurse at Jersey Shore University Medical Center, notified administrators that he would be attending a hearing for a fellow nurse who had been disciplined for raising concerns about SARSCoV-2 exposure at the hospital, he found his photo posted on fliers declaring that he was not allowed on hospital property (Scheiber and Rosenthal 2020).

Such actions also have ample precedent in China. In 2003, during the first few months of the SARS epidemic, the state-controlled Chinese media systematically concealed the truth about SARS from the public. The Minister of Health claimed that the infectious disease "was well under control" and he could "guarantee the safety" of all people coming to Beijing and China. But Dr. Jiang Yanyong, a retired military physician, began sending emails to the Chinese mass media telling what he knew about the epidemic. When he got no response, Jiang sent a letter to foreign news outlets disclosing that at least one hundred people were being treated in Beijing hospitals. Chinese authorities were then forced to admit that they had provided false information about the SARS epidemic (Kahn 2007.)

In the years since the SARS epidemic, authorities have repeatedly placed Jiang under house arrest and prohibited him from traveling abroad to visit his daughter. In 2007, Chinese authorities barred him from going to the United States to receive the Heinz R. Pagels Human Rights of Scientists Award by the New York Academy of Sciences (Kahn 2007). In China's public education system, Jiang is portrayed as a poor role model. A multiple-choice question given by a test-prep 
school in 2017 asked students about Dr. Jiang's decision to disclose information about SARS to the public. The correct answer was: The decision to disclose the truth is wrong because it harms the interests of the nation and society, so anyone doing it ought to be punished by law (Yuan 2020).

A common idiom in the Chinese language is "shi kesha bekeru," which can be translated as, "A person may be killed but should never be humiliated." This saying has its origin in The Book of Rites, one of the canonical texts in Confucianism, edited by Confucius himself more than twenty-five centuries ago. The ethical belief behind the idiom is that human dignity is as important as life itself. If a decent society is a society whose institutions do not humiliate people, then the case of Dr. Li Wenliang and many others demonstrate clearly that China has failed the test of decency.

That failure does not belong to China alone, of course. Whistle-blowers everywhere act for reasons of conscience. Often they feel compelled to speak out against their own organizations in order to maintain their self-respect. "How could I hold my head up if I kept quiet?" the whistle-blower asks. But it is that very sense of self-respect that is targeted and injured in the strategy of humiliation. This is precisely what makes humiliation such a terrifyingly effective tool. Driven to act by their moral principles, whistle-blowers find themselves portrayed as unstable, publicity-seeking traitors. This can be devastating. As Alford asks, "What happens when principles for which one has ruined one's life are regarded by others as mere words?" (Alford 2001, 60).

Yet as flawed as whistle-blower protection practices are in Western countries, at least there is general acknowledgement that such practices are necessary. Western countries largely protect freedom of speech, and the press is open to critical voices. In China, the media and social media constitute a propaganda machine owned and tightly controlled by the Communist Party / government. Whistle-blowers face far greater dangers in China, and censorship is part of everyday life.

Dr. Ai Fen, director of the emergency department at Wuhan Central Hospital, was one of the first physicians to identify a patient with SARS-CoV-2. After she circulated a message to her colleagues, she was reprimanded by the head of the hospital's disciplinary inspection committee for "spreading rumours" and "harming stability." As the virus spread, the hospital went further, telling staff members not to wear protective clothing and banning them from passing messages related to the virus. Ai spoke out publicly in March. "I am not a whistleblower," she told the Chinese magazine Renwu, "I am the one who provided the whistle" (Kuo 2020). Her interview with Renwu was removed soon afterwards and deleted from social media sites. Ai has been missing from public view since March.

\section{References}

Alford, C. 2001. Whistleblowers: Broken lives and organizational power. Ithaca, New York: Cornell University Press.

BBC News. 2020. Li Wenliang: Coronavirus kills Chinese whistleblower doctor. February 7. https://www.bbc. com/news/world-asia-china-51403795. Accessed April 8, 2020 .

Bostock, B. 2020. China declared whistleblower doctor Li Wenliang a "martyr" following a local campaign to silence him for speaking out about the coronavirus. Business Insider, April 3. https://www.businessinsider.com/coronaviruschina-li-wenliang-whistleblower-doctor-martyr-2020-4. Accessed May 1, 2020.

Clarke, D. 2020. Wuhan police "letter of reprimand" to Li Wenliang: Translation and analysis. The China Collection, February 6. https://thechinacollection.org/wuhan-policeletter-reprimand-li-wenliang-translation-analysis/. Accessed May 1, 2020.

Davidson, H. 2020. Chinese inquiry exonerates coronavirus whistleblower doctor. The Guardian, March 20. https://www.theguardian.com/world/2020/mar/20/chineseinquiry-exonerates-coronavirus-whistleblower-doctor-liwenliang. Accessed April 8, 2020.

Green, A. 2020. Li Wenliang. The Lancet 395 (10225): 682.

Ismay, J., and G. Ziezulewicz. 2020. Acting navy secretary slams fired captain as "stupid." The New York Times Magazine, April 6. https://www.nytimes.com/2020/04/06 /magazine/modly-crozier-coronavirus.html. Accessed May 1, 2020.

Kahn, J. 2007. China bars U.S. trip for doctor who exposed SARS cover-up. The New York Times, July 13. https://www. nytimes.com/2007/07/13/world/asia/13 doctor.html. Accessed May 1, 2020.

Kuo, L. 2020. Coronavirus: Wuhan doctor speaks out against authorities. The Guardian, March 11. https://www. theguardian.com/world/2020/mar/11/coronavirus-wuhandoctor-ai-fen-speaks-out-against-authorities. Accessed April $30,2020$.

Lennane, J. 2012. What happens to whistleblowers and why. Social Science and Medicine 6(4): 249-258.

Ma, J., and J. Mai. 2020. Death of coronavirus doctor Li Wenliang becomes catalyst for "freedom of speech" demands in China. South China Morning Post, February 7. https://www.scmp. com/news/china/politics/article/3049606/coronavirusdoctors-death-becomes-catalyst-freedom-speech. Accessed July 5, 2020.

Margalit, A. 1996. The decent society. Translated by N. Goldblum. Cambridge, MA: Harvard University Press. 
The New York Times. 2020. In dialogue with the "whistle-blower": Interview with Dr Li WenLiang before his death [in Chinese]. The New York Times Chinese Version, February 8. https://cn.nytimes.com/china/20200208/li-wenliangchina-coronavirus/. Accessed April 8, 2020.

Qin, J., L. Gao, Z. Bao, and G. Ding. 2020. Li Wenliang, "Whistleblower" on novel coronavirus pneumonia: Truth is most important [in Chinese]. Caixin (Financial News), February 7. http://china.caixin.com/2020-02-07/101509761. html. Accessed April 8, 2020.

Scheiber, N., and B. Rosenthal. 2020. Nurses and doctors speaking out on safety now risk their job. The New York Times, April 9. https://www.nytimes.com/2020/04/09 /business/coronavirus-health-workers-speak-out.html. Accessed May 1, 2020.
Yuan, L. 2020. China silences critics over deadly virus outbreak. The New York Times, January 22. https://www.nytimes. com/2020/01/22/health/virus-corona.html. Accessed April 8, 2020 .

Zhou, C. 2020. Coronavirus: Whistleblower Dr Li Wenliang confirmed dead of the disease at 34, after hours of chaotic messaging from hospital. South China Morning Post, February 7. https://www.scmp.com/news/china/society/article/3049411 /coronavirus-li-wenliang-doctor-who-alerted-authoritiesoutbreak. Accessed May 1, 2020.

Publisher's note Springer Nature remains neutral with regard to jurisdictional claims in published maps and institutional affiliations. 